\title{
POLITIK HUKUM AGRARIA TERHADAP HAK ULAYAT MASYARAKAT HUKUM ADAT DI INDONESIA
}

\author{
Darwin Ginting*
}

\begin{abstract}
This writing on ulayat right of customary law society studies from legal policy perspective, namely a nasional political agrarian law study against ulayat right of current customary law society, and its future prospect in Indonesia. The aim of this agrarian legal policy referring to customary law and ulayat right of customary society during the Dutch colonization was eager to unify and codify the land law which was applied to all walks of life based on concordance, but it failed, so pluralism policy was still applied. This case happens again in Indonesia contemporarily, so it can be predicted that the prospect of ulayat right of pluralistic customary law society still needs to be maintained as it is in harmony and in line with the constitution mandate in the next reformation era in facing globalization impacts by making a combination through the effort of agrarian law reform and land law through a research on the existence of ulayat right of customary law society in each region. From the result of the research, it needs to be acted upon by mapping ulayat right in accordance with the norms of geodetic science, so the scope of ulayat right in Indonesia can be obvious, and eventually it can contribute in supporting the existence and the law certainty of ulayat right in particular, and land law in general
\end{abstract}

Key words: legal policy, agrarian law, customary law, ulayat right

\begin{abstract}
Abstrak
Hak ulayat masyarakat hukum adat dalam tulisan ini ingin mengkaji dari sudut kebijakan hukum (legal policy), yakni suatu kajian politik hukum agraria nasional terhadap hak ulayat masyarakat hukum adat sekarang ini dan prospeknya dimasa-masa yang akan datang di Indonesia. Arah kebijakan hukum (legal policy) agraria berkenaan dengan hukum adat dan hak ulayat (beschikkingsrecht) masyarakat adat masa kolonial Belanda berkeinginan untuk unifikasi dan kodifikasi hukum pertanahan yang berlaku untuk seluruh golongan masyarakat berdasarkan asas konkordansi, namun gagal total, sehingga tetap diterapkan kebijakan pluralisme. Hal ini kembali terjadi di Indonesia secara kontemporer, sehingga dapat diprediksi bahwa prospek hak ulayat masyarakat hukum adat yang pluralis masih harus dipertahankan karena selaras dengan amanat konstitusi dalam era reformasi selanjutnya dalam menghadapi terpaan globalisasi dengan cara melakukan kombinasi dengan upaya pembaharuan hukum agrarian dan hukum tanah lewat penelitian (riset) tentang ada tidaknya
\end{abstract}

${ }^{*}$ Lektor Kepala Dosen Tetap pada Sekolah Tinggi Hukum Bandung dan Program Magister Hukum Sekolah Tinggi Hukum Bandung. Alamat kontak: dr.darwinginting_sh@yahoo.co.id 
hak ulayat masyarakat hukum adat di masing-masing daerah, Dari hasil penelitian perlu ditindak lanjuti dengan melakukan pemetaan hak ulayat sesuai kaidah-kaidah Ilmu Geodesi, sehingga terlihat jelas luasan hak ulayat yang ada di Nusantara dan pada akhirnya dapat berkontribusi dalam menunjang eksistensi dan kepastian hukum hak ulayat secara khusus dan hukum tanah pada umumnya.

Kata kunci: kebijakan hukum, hukum agraria, hukum adat, hak ulayat.

\section{Pendahuluan}

Dalam konteks kesejarahan sesungguhnya kita amat beruntung, karena perancang Undang-Undang Dasar 1945 Prof. Soepomo adalah seorang pakar hukum adat, yang benar-benar mengetahui posisi masyarakat adat di Indonesia dan sehubungan dengan itu mencantumkan pengakuan Negara terhadap masyarakat hukum adat dalam rancangan konstitusi yang sedang di susunnya.Tetapi di sayangkan, bahwa pengakuan tersebut tidak tercantum secara lugas dalam dicktum Undang-Undang Dasar 1945, tetapi hanya dalam penjelasan Pasal $18 .^{1}$

Namun walaupun hanya tercantum dalam penjelasan Pasal 18 UUD 1945 sikap para Founding Fathers tersebut merupakan pendapat original yang harus dirujuk dalam melakukan tafsiran historis terhadap norma hukum yang terkait dengan eksistensi dan hak-hak tradisional masyarakat hukum adat.

Sampai sekitar tahun 1960 pengakuan konstitusional terhadap masyarakat hukum adat dan hak-haknya tidak banyak dipersoalkan. Faktor penyebabnya adalah karena jaminan tersebut sudah dianggap seyogianya demikian, sebagian lagi oleh karena Republik Indonesia masih sibuk dalam mempertahankan kemerdekaan. Namun perlindungan terhadap eksistensi dan hak-hak masyarakat hukum adat merosot tajam sejak tahun 1960, seiiring dengan meningkatnya kepentingan negara terhadap sumber daya alam, yang terdapat dalam wilayah hak ulayat masyarakat hukum adat, terutama di luar pulau Jawa. Dengan berbagai peraturan perundang-undangan, Negara mengambil berbagai kebijakan yang intinya adalah mengurangi, membatasi hak-hak tradisional serta hak masyarakat hukum adat yang ada, tanpa memberikan ganti rugi sama sekali.

Secara khusus perlu kita catat sikap ambivalen yang dianut oleh UndangUndang Pokok Agraria Nomor 5 Tahun 1960 Tentang Pokok-pokok Agraria terhadap hukum adat dan masyarakat hukum adat. Pada suatu sisi Undang-undang ini secara tegas menyatakan bahwa hukum adat merupakan sumber dari Hukum Agraria Nasional kita. Namun pada sisi lain eksistensi masyarakat hukum adat

\footnotetext{
${ }^{1}$ Pada angka II Penjelasan Pasal 18 tersebut termaktub kalimat ini: "Dalam teritori Negara Indonesia terdapat lebih kurang 250 Zelfbesturende Landschappen" dan "Volksgmeenschappen seperti desa Jawa dan Bali, negeri di Minangkabau, dusun dan marga di Palembang dan sebagainya. Daerah-daerah itu mempunyai susunan asli, dan oleh karenanya dapat dianggap sebagai daerah yang bersifat istimewa. Negara Republik Indonesia menghormati kedudukan daerah-daerah istimewa tersebut dan segala peraturan Negara yang mengenai daerah itu akan mengingat hak-hak asal-usul daerah itu".
} 
dan hak-haknya dibebani beberapa kondisionalitas yang cepat atau lambat membuka peluang untuk dimarginalkannya masyarakan hukum adat tersebut.

Dalam kondisi tersebut masyarakat hukum adat tidak berdiam diri terhadap pengurangan, pembatasan atau pencabutan hak-haknya. Di seluruh Nusantara terjadi protes bahkan perlawanan terbuka dari masyarakat hukum adat, yang pada umumnya gagal untuk mempertahankan keberadaannya dan hak-hak tradisionalnya. Hal ini terjadi karena masyarakat hukum adat tidak mempunyai akses pada kekuasaan.

Keadaan yang secara sistematis yang meminggirkan masyarakat hukum adat dan hak-haknya seperti itu secara umum berlangsung terus sejak tahun 1960 1998, sewaktu secara bertahap memasuki era reformasi telah diletakkan kembali landasan hukum untuk pengakuan formal terhadap eksistensi hak-hak tradisional masyarakat hukum adat sebagaimana yang diamanatkan UUD 1945 yang telah diamanden.

Memperbincangkan secara ilmiah mengenai beschikkingsrecht (hak ulayat) masyarakat hukum adat merupakan hal yang cukup menarik di era reformasi sekarang ini. Karena persoalan pertanahan di Indonesia pada masa orde baru sangat didominasi oleh kebijakan pertanahan (land policy) yang cenderung sentralistik telah mengabaikan hak-hak masyarakat adat atas tanah. Keadaan ini kembali berbalik pada saat setelah tumbangnya kekuasaan orde baru di panggung politik Indonesia (21 Mei 1997) yang lebih mengarah pada upaya desentralisasi di bidang pertanahan, mutatis mutandis konservasi hak-hak masyarakat adat atas tanah. ${ }^{2}$ Implikasi yang lebih luas lagi adalah semakin hangatnya diskusi-diskusi tentang masalah keagrariaan nasional sebagai kritik terhadap kebijakan pertanahan selama ini yang tidak berpihak kepada masyarakat hukum adat. ${ }^{3}$

Menjadi lebih penting dan menarik lagi bila persoalan hak ulayat masyarakat hukum adat tersebut di atas dikaji dari sudut kebijakan hukum (legal policy), yakni suatu kajian politik hukum agraria nasional terhadap hak ulayat masyarakat hukum adat di Indonesia sekarang ini. Untuk itu penulis sangat terdorong untuk mengkaji secara khusus mengenai persoalan di sekitar kebijakan hukum agraria berkenaan dengan hak ulayat masyarakat hukum adat atas tanah di Indonesia yang nota bene adalah negara berkembang (developing countries), bahkan sekarang sudah dapat disebut sebagai negara miskin atau terbelakang (less developed countries). ${ }^{4}$ Urgensinya adalah agar kembali ditemukan akar masalah hukum terhadap hak-hak atas tanah bagi indigenous people (masyarakat pribumi atau masyarakat asli) yang sewajarnya perlu perlindungan hukum serta kemauan politik pemerintah (political will).

${ }^{2}$ Bandingkan: Eddy Ruchiyat, "Politik Pertanahan Nasional Sampai Orde Reformasi", (Bandung: Alumni, 1999), hal. 109-111.

${ }^{3}$ Bandingkan: Ellydar Chaidir, Desentralisasi Pengelolaan Sumber Daya Alam Dalam Perpektif Undang-Undang Nomor 22 Tahun 1999, Jurnal Hukum Ius Quia Iustum No. 14 Vol. 7 Universitas Islam Indonesia, Yogyakarta, 2000, 149.

${ }^{4}$ Bandingkan: Teuku May Rudy, "Masalah Negara Berkembang: Suatu Kajian Ekonomi Politik Internasional", (Bandung: Bina Budaya, 2004), hal. 1. 
Berbicara politik hukum tentang hak ulayat secara khusus, sama sekali tidak dapat dilepaskan dengan politik hukum agraria secara umum. Kemana arah kebijakan hukum agraria nasional dibuat, juga secara otomatis melekat hak ulayat. Bilamana politik hukum agraria nasional itu responsif, maka dengan sendirinya kebijakan hukum terhadap hak ulayat akan responsif pula. Moh. Mahfud MD, ${ }^{5}$ menegaskan:

\begin{abstract}
UUPA juga memberikan tempat yang proporsional bagi hukum adat, seperti yang tersebut dalam Pasal 5 bahwa hukum agraria yang berlaku atas bumi, air dan ruang angkasa adalah hukum adat yang sudah disaneer dan tidak bertendensi menantang asas unifikasi. Ini menandakan UUPA berkarakter responsif, sebab hukum yang memiliki hukum adat dapat dilihat sebagai hukum yang responsif. Marryman menyebut tradisi hukum adat menganut strategi pembangunan hukum yang responsif.
\end{abstract}

Jadi, karakter responsif Undang-Undang Nomor 5 Tahun 1960 tentang Peraturan Dasar Pokok-Pokok Hukum Agraria tercermin pada norma yang terkandung dalam Pasal 5 bahwa hukum agraria yang berlaku atas bumi, air dan ruang angkasa ialah hukum adat, sepanjang tidak bertentangan dengan kepentingan nasional dan negara, yang berdasarkan atas persatuan bangsa, dengan sosialisme Indonesia serta dengan peraturan-peraturan yang tercantum dalam undang-undang ini dan dengan peraturan perundangan lainnya, segala sesuatu dengan mengindahkan unsur-unsur yang bersandar pada hukum agama.

Norma perlindungan hak ulayat masyarakat hukum adat dalam peraturan perundang-undangan keagrariaan di Indonesia merupakan indikasi responsifnya hukum agraria nasional. Sebab jaminan perlindungan hak-hak masyarakat hukum adat atas tanah merupakan syarat mutlak peraturan perundang-undangan keagrariaan nasional, hal ini merupakan amanat konstitusi sebagaimana yang diatur dalam hukum positif Indonesia mengenai hak-hak masyarakat adat dapat dirujuk pada Pasal 18B ayat (2) UUD 1945 yang menegaskan: "Negara mengakui dan menghormati kesatuan-kesatuan masyarakat hukum adat beserta hak-hak tradisionalnya sepanjang masih hidup dan sesuai dengan perkembangan masyarakat dan prinsip Negara kesatuan Republik Indonesia yang diatur dalam undang-undang". Kemudian dalam Pasal 281 ayat (3) UUD 1945 ditegaskan bahwa: "Identitas budaya dan hak masyarakat tradisional dihormati selaras dengan perkembangan zaman dan peradaban".

Jaminan konstitusional di atas kemudian dapat ditelusuri dalam UUPA, khususnya dalam Pasal 5 UUPA yang menyebutkan bahwa hukum agraria nasional didasarkan pada hukum adat. Ini berarti bahwa kekuatan hukum hak-hak atas tanah bagi masyarakat hukum adat sangat dijamin dalam hukum positif Indonesia. ${ }^{6}$

${ }^{5}$ Moh. Mahfud MD, "Politik Hukum Di Indonesia", (Jakarta: Pustaka LP3ES Indonesia, 1998), hal. 347. 
Keberadaan hak ulayat itu perlu dipastikan mengingat pengertian masyarakat hukum adat masih terdapat penafsiran yang berbeda, sehingga sering terjadi "marginalisasi" masyarakat adat.

Melihat kenyataan ini, maka beberapa aliansi masyarakat hukum adat menuntut hak agar mereka diakui keberadaannya dan juga hak-hak masyarakat adatnya. Hak-hak masyarakat adat ini merupakan hak dasar manusia pada umumnya di dunia. Berlakunya universal, karena itu dalam membicarakan perlindungan hak-hak penduduk lokal dapat ditarik dari teori "menentukan nasib sendiri" dalam kerangka Negara kesatuan. ${ }^{7}$ Tentang eksistensi hak ulayat itu sendiri terdapat 2 (dua) pandangan sikap, di satu pihak terdapat kekhawatiran bahwa hak ulayat itu semula tidak ada, kemudian dihidupkan lagi. Di pihak lain ada juga kekhawatiran bahwa dengan semakin meningkatnya kebutuhan akan tanah akan semakin mendesak hak ulayat. ${ }^{8}$ Terlebih lagi dengan dimunculkannya berbagai persyaratan akan eksistensi dan implementasi hak ulayat (beschikkingsrecht) masyarakat adat. Pertama, mengenai eksistensinya, apabila menurut kenyataan masih ada. Di daerah mana hak itu tidak ada lagi atau memang tidak pernah ada, tidak akan dihidupkan lagi bahkan tidak akan dilahirkan hak ulayat yang baru. Kedua, mengenai pelaksanaan hak ulayat harus sedemikian rupa, sehingga (1). sesuai dengan kepentingan nasional dan negara berdasarkan atas persatuan bangsa, serta (2). tidak boleh bertentangan dengan undang-undang dan peraturan-peraturan yang lebih tinggi. ${ }^{9}$

Pengakuan dengan syarat terhadap hak ulayat tersebut mencerminkan pengaturan secara sistimatis mengenai pengidentifikasian dan penggunaan hak ulayat atas tanah di Indonesia. Sehingga memunculkan kritik yang mendasar: Pertama, belum jelasnya indikasi pemahaman tentang hak ulayat yang hilang atau yang sudah tidak ada, sehingga pada implementasinya akan dapat disalahgunakan oleh pihak penguasa untuk menghilangkan hak ulayat. Kedua, masih begitu dominannya negara atau pemerintah dengan "topeng" kepentingan umum terhadap tanah, sehingga terkadang mengintervensi ruang hidup (labensraum, livingspace) komunitas masyarakat pemilik hak ulayat. Apakah dengan alasan kepentingan umum dapat menghapus norma-norma adat yang berkenaan dengan hak ulayat. Ketiga, argumentasi bertentangan dengan peraturan perundangundangan yang berlaku berarti telah menafikan eksistensi hukum adat itu sendiri. Padahal Undang-Undang Nomor 5 Tahun 1960 mendeklarasikan dirinya bahwa hukum agraria yang berlaku atas bumi, air dan ruang angkasa ialah hukum adat. ${ }^{10}$

${ }^{6}$ Bandingkan: Arie S. Hutagalung, "Tebaran Pemikiran Seputar Masalah Hukum Tanah, Jakarta, Lembaga Pemberdayaan Hukum Indonesia", (Jakarta: LPHI, 2005), hal. 120.

7 S. James Anaya, "Indegenous Peoples International Law", (New York: Oxford University Press, 1994), hal. 89.

${ }^{8}$ Maria S.W. Sumardjono, "Kebijakan Pertanahan; Antara Regulasi dan Implementasi", (Jakarta: Penerbit Buku Kompas, 2001), hal. 54.

9 Hasan Wargakusumah, et.al., "Hukum Agraria; Buku Panduan Mahasiswa", (Jakarta: Prenhallindo, 2001), hal. 55. 
Kritik tersebut sebenarnya ingin mempertegas perbedaan antara cara-cara negara jajahan dan negara komunis dalam memperlakukan hak-hak rakyat mengenai tanah. A.P. Parlindungan ${ }^{11}$ menyatakan bahwa:

Berbeda dengan negara-negara penjajah maupun di negara-negara komunis yang mulai mengambil alih daerah tersebut pada umumnya tidak mengakui hak-hak rakyat yang terdahulu dan hanya menyatakan bahwa 'karena raja-rajanya sudah menyerah, maka seluruh tanah adalah milik dari penjajah' ataupun di negara-negara komunis ketika mereka mulai berkuasa, dianggap semua tanah adalah milik rakyat dan sepenuhnya dikuasai dan dimiliki oleh negara, sehingga milik pribadi dihapuskan.

Pendapat ini memberi pemahaman bahwa agar terhindar dari kesewenangwenangan negara dalam memperlakukan hak-hak rakyat akan tanah, maka perlu pengakuan yang lebih serius dalam hak hak ulayat masyarakat adat. Bahkan lebih dari itu, dalam rangka pemberian suatu hak atas tanah (umpamanya, hak guna usaha), harus ditanyakan kembali dan mendengar pendapat masyarakat hukum yang bersangkutan (recognitie), ${ }^{12}$ karena mereka mempunyai akses yang besar, sehingga masyarakat hukum adat akan terkena dampak terhadap pengelolaan tanah dan sumber daya alam yang akan dibebani hak baru dimaksud.

Konflik mengenai tanah ulayat sering terjadi dibeberapa daerah Indonesia, misalnya di Aceh, Sumatera Utara, Sumatera Barat, Riau, Kalimantan Barat, Kalimantan Tengah, Kalimantan Timur, Maluku, Ambon, dan Wamena - Papua. ${ }^{13}$ Perlawanan masyarakat hukum adat juga terjadi di Sumatera Selatan, Riau, Bulu Kumba (Sulawesi), dan Wamena. ${ }^{14}$ Kondisi tersebut diperkuat dengan pernyataan Deputi Sekretaris Jenderal Konsersium Pembaharuan Agraria (KPA) Iwan Nurdin, sebagaimana yang dinyatakan bahwa sepanjangan tahun 2012 konflik agraria merata di Indonesia, konflik dan sengketa lahan yang dibiarkan dapat berujung pada konflik sosial, sehingga seharusnya pemerintah harus mengambil peran di dalam penyelesaian masalah tersebut khususnya Badan Pertanahan Nasional yang mempunyai otoritas untuk itu. ${ }^{15}$

${ }^{10}$ Lihat : Pasal 5 Undang-Undang Nomor 5 Tahun 1960.

${ }^{11}$ AP. Parlindungan, "Konversi Hak-Hak Atas Tanah", (Bandung: Mandar Maju, 1994), hal. 17.

${ }^{12}$ Boedi Harsono, "Hukum Agraria Indonesia; Himpunan Peraturan-Peraturan Hukum Tanah", (Jakarta: Djambatan, 2002), hal. 33.

${ }^{13}$ Agung Pryo Sarjono, Konflik Sosial di Kalimantan Timur, Hutan Indonesia, Edisi 07, II/Maret 2000, hal. 14.

14 Berdayakan Masyrakat Hukum Adat untuk Perlindungan Lingkungan, Tempt/HOCVPO7L, hal. 1.

${ }^{15}$ Harian Kompas, Selasa tanggal 29 Mei 2001. 
Menurut penulis dalam kondisi sekarang ada kecenderungan konflik mengenai tanah ulayat ini makin merata di seluruh Indonesia khususnya diluar pulau Jawa, oleh karena itu sudah saatnya pemerintah dalam hal ini Presiden harus turun tangan mengakomodir kepentingan masyarakat adat. Karena konflik lahan dapat menjadi bom waktu yang dapat menganggu aspek sosial dan politik.

Sebagai perbandingan di Negara Malaysia juga ditemukan sejenis hak ulayat di Indonesia, disebut dengan nama tanah Simpanan Melayu. Tanah Simpanan Melayu ialah suatu kawasan tanah yang tertentu khusus untuk orangorang Melayu, artinya orang bukan Melayu sekalipun ia warga negara Malaysia, tidak bisa menjadi subyek tanah Simpanan Melayu. ${ }^{16}$ Di negara bagian Malaka dan Negeri Sembilan disebut sebagai Tanah Pegangan adat. ${ }^{17}$ Sebagian besar tanah simpanan Melayu terdapat dikampung-kampung, kawasan hutan-hutan belantara dan keseluruhan tanah termasuk tanah yang tidak subur (bermutu rendah). Luas tanah simpanan melayu di Semenanjung Malaysia selalu berubahubah, karena terjadi peralihan hak, tetapi tidak terdata secara akurat. Luas Tanah Simpanan Tanah Melayu dapat dilihat dalam tabel di bawah ini:

Tabel 1

Luas Tanah Simpanan Melayu(Tanah Ulayat) Tahun 1983 Se-Malaysia

\begin{tabular}{|l|l|l|l|}
\hline No. & Negara Bagian & Keluasan (Ekar) & Luas (Hektar) \\
\hline 1 & Kelantan & $3.689 .599,7$ & 1.493 .765 \\
\hline 2 & Perak & $416.879,5$ & 168.777 \\
\hline 3 & Pahang & $663.131,29$ & 268.474 \\
\hline 4 & Kedah & 1.675 .777 & 654.160 \\
\hline 5 & Johor & $547.323,55$ & 221.588 \\
\hline 6 & Negeri Sembilan & 545.231 & 220.741 \\
\hline 7 & Perlis & $\mathbf{8 4 . 2 7 6 , 4}$ & 34.120 \\
\hline 8 & Trengganu & 226 & 107 \\
\hline 9 & Wilayah Persekutuan & $4.441,1$ & 988,28 \\
\hline 10 & Selangor & $391.180,8$ & $158.372,79$ \\
\hline 11 & Malaka & $10.745,66$ & $4.348,61$ \\
\hline & Jumlah & $7.956 .066,34$ & $3.221 .075,48$ \\
\hline
\end{tabular}

Sumber: Pengarah Tanah Dan Galian Semenanjung Malaysia.

Dari jumlah 3 juta hektar tanah Simpanan Melayu, diperkirakan 800.000 hektar telah hilang dan dilepas karena digunakan untuk pembangunan negara atau terjadi peralihan hak. ${ }^{18}$ Dari data tersebut terlihat, bahwa di Malaysia ada upaya

${ }^{16}$ Saleh Buang, "Undang-Undang Tanah di Malaysia", (Selangor Darul Eksam: Dewan Bahasa dan Pustaka Lot 1037, 1993), hal. 168.

\footnotetext{
1987), hal. 4.

${ }^{17}$ Moh. Ridwan Bin Awang, "Tanah Simpanan Melayu”, (Malaysia: Rich'me Enterprise,
} 
pemetaan terhadap hak adat atas tanah, sedangkan negara kita belum pernah melakukan upaya kearah tersebut, sehingga kedepan perlu kita pertimbangkan plus minusnya. Menurut penulis pendataan luas Hak Ulayat seyogianya perlu dilakukan secara cermat dan hati-hati, sehingga dapat mencegah konflik dan sengketa-sengketa tanah hak ulayat seperti kasus sengketa tanah kebun kelapa sawit, demikian pula kasus Freeport yang sampai hari ini tidak pernah tuntas. Upaya pendataan luas hak ulayat bukan berarti mempertahankan keberadaannya, karena hak ulayat akan terhapus secara alamiah karena dampak pembangunan yang berjalan terus. Hal ini terbukti di pulau jawa tidak ada lagi hak ulayat karena pembangunan fisik dan nonfisik hampir telah merata.Dampak positip lanjutan dari upaya pendataan hak ulayat kedepan dapat menunjang kepastian hukum bagi masyarakat adat secara khusus dan Hukum Tanah Nasional pada umumnya.

\section{Pengertian Politik Hukum dan Politik Hukum Agraria}

Perihal pengertian politik hukum di Indonesia, terdapat 2 (dua) aliran pendapat. Pertama, politik hukum dipahami sebagai kebijakan tentang hukum. Kedua, politik hukum dipahami bahwa hukum sebagai produk politik. Pada aliran yang pertama terdapat beberapa pakar hukum yang menganutnya, seperti Padmo Wahyono, ${ }^{19}$ yang memberi batasan tentang politik hukum bahwa: "politik hukum sebagai kebijaksanaan penyelenggara negara tentang apa yang dijadikan kriteria untuk menghukumkan sesuatu. Kebijaksanaan tersebut dapat berkaitan dengan pembentukan hukum, penerapan hukum, lembaga penegak hukum dan penegakannya sendiri". Singkatnya Padmo menyatakan bahwa "politik hukum sebagai kebijakan dasar yang menentukan arah, bentuk maupun isi hukum yang akan dibentuk".

Demikian pula dengan Teuku Muhammad Radhie ${ }^{20}$ yang menyatakan bahwa: "politik hukum sebagai pernyataan kehendak penguasa negara mengenai hukum yang berlaku di wilayahnya dan mengenai arah ke mana hukum hendak dikembangkan". Juga Sudarto ${ }^{21}$ yang memberi pengertian bahwa: "politik hukum adalah kebijakan dari negara melalui badan-badan yang berwenang menetapkan peraturan-peraturan yang dikehendaki, yang diperkirakan dan digunakan untuk mengekspresikan apa yang terkandung dalam masyarakat dan untuk mencapai apa yang dicita-citakan". Pendapat Padmo Wahyono, Teuku Mohhammad Radhie dan Soedarto tersebut ternyata berbeda dengan pengertian politik hukum yang dikemukakan Purnadi Purbacaraka \& Soerjono Soekanto ${ }^{22}$ yang memberi

${ }^{18}$ Ibid.

19 Padmo Wahyono, "Menyelidik Proses Terbentuknya Perundang-undangan", (Jakarta: Forum Keadilan, 1992), hal. 65.

20 Sri Soemantri Martosoewignjo, "Materi Kuliah Politik Hukum", (Bandung: Program Pascasarjana Universitas Padjadjaran, 2002), hal. 2.

${ }^{21}$ Ibid., hal. 3 . 
definisi tentang politik hukum, yakni "politik hukum sebagai kegiatan-kegiatan memilih nilai-nilai dan menerapkan nilai-nilai". Mencermati pengertian politik hukum ini, maka terlihat jelas keluasannya. Sebab pengertian ini luas karena menempatkan politik hukum sebagai salah satu bagian dari disiplin hukum.

Penganut aliran pikiran politik hukum yang kedua ialah Moh. Mahfud $\mathrm{MD}{ }^{23}$ yang mengatakan bahwa berbicara politik hukum berarti kita membicarakan hubungan timbal balik antara politik dengan hukum. Karena itu, tidak dapat disangkal bahwa konfigurasi politik tertentu akan mempengaruhi karakter produk hukum. Tegasnya, Moh. Mahfud $\mathrm{MD}^{24}$, merumuskan definisinya sebagai berikut:

\section{Politik hukum secara sederhana dapat dirumuskan sebagai kebijaksanaan hukum (legal policy) yang akan atau telah dilaksanakan secara nasional oleh pemerintah; mencakup pula pengertian tentang bagaimana politik mempengaruhi hukum dengan cara melihat konfigurasi kekuatan yang ada di belakang pembuatan dan penegakan hukum itu.}

Dalam pandangan Mahfud, hukum tidak dapat hanya dipandang sebagai pasal-pasal yang bersifat imperatif atau keharusan-keharusan yang bersifat das sollen, melainkan harus dipandang sebagai sub sistem yang dalam kenyataan (das sein) bukan tidak mungkin sangat ditentukan oleh politik, baik dalam perumusan materi dan pasal-pasalnya maupun dalam implementasi dan penegakannya. ${ }^{25}$

Berangkat dari pengertian politik hukum di atas, maka dapat memberi kedekatan pemahaman bahwa politik hukum agraria nasional adalah arah kebijakan hukum agraria yang isi dan bentuknya dibuat oleh para penentu beleid negara berdasarkan konfigurasi politik yang mempengaruhinya pada saat itu. Adapun politik hukum Agraria adalah sebagaimana yang diamanatkan dalam Pasal 33 ayat (3) UUD 1945 yang kemudian diokomodir Pasal 2 ayat (1) UUPA bahwa, bumi, air dan ruang angkasa termasuk kekayaan alam yang terkandung didalamnya harus dipergunakan untuk kesejahteraan rakyat. Hasil yang akan dicapai dalam mempelajari politik hukum adalah apakah suatu aturan hukum yang hendak dibuat atau telah dibuat akan mengarah kepada terciptanya suatu: (1). unifikasi hukum - kodifikasi hukum, ataukah (2). pluralisme atau pluralisasi hukum (dualisme hukum), ataukah (3). simplifikasi (penyederhanaan) hukum, atau (4). penyelarasan hukum. ${ }^{26}$ Sasaran kebijakan hukum atau politik hukum

${ }^{22}$ Purnadi Purbacaraka \& Soerjono Soekanto, "Disiplin Hukum dan Disiplin Sosial", (Jakarta: Rajawali, 1986), hal. 5.

\footnotetext{
${ }^{23}$ Moh. Mahfud MD, Op. Cit., hal. 15.

${ }^{24}$ Ibid., hal. $1-2$.

${ }^{25}$ Ibid., hal. 2.
} 
(legal policy) ini, yang kemudian dalam tulisan ini menurut hemat penulis akan mengkaji tentang bagaimana arah politik hukum agraria nasional berkenaan dengan perlindungan atau pengakuan atas hukum adat (khususnya hak ulayat masyarakat hukum adat) di era reformasi.

\section{Pengertian dan Peristilahan Hukum Agraria}

Kata "agraria" berasal dari istilah agrarius, ager (Latin) atau agros (Yunani), akker (Belanda) yang artinya tanah pertanian. ${ }^{27}$ Istilah "agraria" ini dalam Kamus Besar Bahasa Indonesia ${ }^{28}$ diartikan sebagai: "urusan tanah pertanian atau urusan pemilikan tanah". Sedangkan dalam Black's Law Dictionary disebutkan bahwa "agraria" itu relating to land or to a division or distribution of land; esp, from land or land ownership; Agrarian laws (problems, disputes). ${ }^{29}$ Istilah "agraria" sebagai kata benda (noun) berbeda dengan agraria yang digolongkan sebagai kata sifat (adjective) yang dipergunakan untuk membedakan corak kehidupan (ekonomi) masyarakat pertanian di pedesaan dari masyarakat non-agraris (perdagangan dan industri di perkotaan) ${ }^{30}$

Setelah membahas istilah "agraria", maka penulis ingin memapar-kan istilah "hukum agraria". Sebagaimana diketahui bahwa di samping istilah "hukum agraria" (agrarian law) yang telah digunakan oleh para ahli hukum agraria, juga ada istilah "hukum tanah" atau "hukum pertanahan" (land law). Penulis dalam hal ini cenderung sependapat dengan alasan yang menggunakan istilah "hukum agraria", yang menyatakan bahwa hukum agraria tidak hanya mengatur tentang tanah saja, tetapi lingkupnya meliputi seluruh bumi, air dan ruang angkasa termasuk kekayaan alam yang terkandung didalamnya. Sedangkan istilah "hukum tanah" hanya mencakup pengaturan tentang tanah, yakni permukaan bumi. ${ }^{31}$ Oleh sebab itu, hukum agraria merupakan genus dari species hukum tanah. Atau dengan lain perkataaan bahwa hukum agraria meliputi pula hukum tanah, atau hukum tanah adalah bagian dari hukum agraria. ${ }^{32}$

${ }^{26}$ Bandingkan: Soetandyo Wignjosoebroto, "Dari Hukum Kolonial Ke Hukum Nasional; Suatu Kajian Tentang Dinamika Sosial - Politik Dalam Perkembangan Hukum Selama Satu Setengah Abad di Indonesia ( 1840 - 1990)", (Jakarta: RajaGrafindo Persada, 1995), hal. 9 - 11.

${ }^{27}$ Hasan Wargakusumah, et.al., Op. Cit., hal. 5.

${ }^{28}$ Tim Penyusun Kamus Pusat Pembinaan dan Pengembangan Bahasa, "Kamus Besar Bahasa Indonesia", (Jakarta: Departemen Pendidikan dan Kebudayaan bekerja sama dengan Balai Pustaka, 1995), hal. 11.

${ }^{29}$ Hasan Wargakusumah, et.al., Op. Cit., hal. 5.

${ }^{30}$ Ibid., hal. 5.

${ }^{31}$ K.Wantjik Saleh, Op. Cit., hal. 10.

${ }^{32}$ Ibid., hal. 11. 
Menurut Boedi Harsono, ${ }^{33}$ hukum Agraria bukan hanya merupakan satu perangkat bidang hukum. Hukum Agraria merupakan satu kelompok berbagai bidang hokum (interdisipliner), yang masing-masing mengatur hak-hak penguasaan atas sumber-sumber daya alam tertentu yang termasuk pengertian agraria. Menurut Boedi Harsono, ${ }^{34}$ kelompok berbagai bidang hukum tersebut adalah:

i. Hukum Tanah, yang mengatur hak-hak penguasaan atas tanah, dalam arti permukaan bumi.

ii. Hukum Air, yang mengatur hak-hak penguasaan atas air.

iii. Hukum Pertambangan, yang mengatur hak-hak penguasaan atas bahanbahan galian yang dimaksudkan oleh Undang-Undang Pokok Pertambangan.

iv. Hukum Perikanan, yang mengatur hak-hak penguasaan atas kekayaan alam yang terkandung di dalam air.

v. Hukum Penguasaan atas Tenaga dan Unsur-unsur dalam ruang angkasa, mengatur atas tenaga dan unsur-unsur dalam ruang angkasa yang dimaksudkan oleh Pasal 48 UUPA.

G. Kartasapoetra, et.al. ${ }^{35}$ dinyatakan bahwa: hukum agraria adalah hukum yang mempersoalkan masalah pertanahan atau yang terdiri dari sekumpulan norma yang mengatur manusia dalam masalah pertanahan agar tanah tersebut bermanfaat bagi kesejahteraan manusia. Definisi ini ternyata masih sangat sempit sekali, hal ini terlihat dari uraian pengertian yang disebutkan adalah "tanah". Padahal telah penulis jelaskan di atas bahwa berbicara tanah hanyalah permukaan bumi, sedangkan air dan ruang angkasa tidak tercakup didalamnya. Oleh sebab itu, sebaiknya definisi tersebut perlu dilengkapi dengan kata "air", "ruang angkasa" dan "kekayaan alam yang ada didalamnya".

Menurut C.S.T. Kansil, ${ }^{36}$ hukum agraria didefinisikan sebagai berikut: "hukum agraria ialah keseluruhan kaidah-kaidah hukum, baik yang tertulis maupun tidak tertulis yang mengatur agraria." Sedangkan "Agraria" itu sendiri menurut Kansil, meliputi bumi, air dan kekayaan alam yang terkandung didalamnya, bahkan dalam batas-batas yang ditentukan juga ruang angkasa. ${ }^{37}$ Mungkin pendapat ini agak sedikit maju, karena sudah menyebut cakupan dari hukum agraria yang terdiri atas bumi, air, ruang angkasa serta kekayaan alam yang ada didalamnya. Di samping itu, definisi tersebut memberikan penekanan

33 Boedi Harsono, "Hukum Agraria Indonesia; Sejarah Pembentukan Undang-Undang Pokok Agraria, Isi dan Perkembangannya", (Jakarta: Djambatan, 2003), hal. 8.

${ }^{34} \mathrm{Ibid}$.

${ }^{35}$ G.Kartasapoetra, et.al., Op. Cit., hal. 84.

${ }^{36}$ C.S.T.Kansil, "Pengantar Ilmu Hukum dan Tata Hukum Indonesia", (Jakarta: Balai Pustaka, 1989), hal. 318.

${ }^{37}$ Ibid. 
terhadap sekumpulan kaidah-kaidah. Kaidah dalam hal ini adalah norma itu sendiri, baik norma hukum yang tertulis maupun yang tidak tertulis. Norma hukum yang tidak tertulis adalah hukum adat yang bersangkut paut dengan masalah pertanahan.

\section{Doktrin Para Ahli dan Pengaturan Hukum tentang Hak Ulayat Atas Tanah}

Mendiskusikan hak ulayat atas tanah (beschikkingsrecht) tidak dapat dipisahkan dari keberadaan hukum adat di Indonesia itu sendiri, karena habitat hak ulayat dalam pandangan hukum sesungguhnya berada pada komunitas masyarakat hukum adat. Mengapa demikian?, karena secara faktual, konseptual dan perseptual, hukum adat memandang masyarakat sebagai suatu "paguyuban". Menurut M.M. Djojodigoeno: ${ }^{38}$

Hukum adat memandang masyarakat sebagai paguyuban, artinya sebagai satu hidup bersama, di mana manusia memandang sesama manusia sebagai tujuan, di mana manusia menghadapi sesama manusia dengan segala perasaannya, dengan segala sentimennya, sebagai cinta, benci, simpati, antipati, empati dan sebagainya yang baik dan yang kurang baik.

Sebagai sebuah komunitas, maka masyarakat hukum adat jelas membentuk peradaban-peradaban tertentu, seperti: adat istiadat perkawinan, prosesi kematian, termasuk kearifan dan tata cara memperoleh dan memanfaatkan tanah. Tata cara memperoleh dan mengolah tanah dimaksud yang kemudian melahirkan apa yang dikenal dengan "hak ulayat" (beschikkingsrecht).

Mr. CCJ. Maasen dan A.P.G. Hens ${ }^{39}$ dalam bukunya Agrarische Regeling Voor Het Gouvernmentsgebeid van Java en Madura (Peraturan-Peraturan Agraria Di Daerah Gubernemen Jawa dan Madura) menerangkan bahwa:

Yang dinamakan hak ulayat (beschikkingsrecht) adalah hak desa menurut adat dan kemauannya untuk menguasai tanah dalam lingkungan daerahnya buat kepentingan anggota-anggotanya atau untuk kepentingan orang lain (orang asing) dengan membayar kerugian kepada desa, dalam hal mana desa itu sedikit banyak turut campur dengan pembukaan tanah itu dan turut bertanggung jawab terhadap perkara-perkara yang terjadi di situ yang belum dapat diselesaikan.

\footnotetext{
${ }^{38}$ Terpetik dalam: Ali Afandi, "Kedudukan Hukum Asing Dalam Pembinaan Tata Hukum Di Indonesia", (Jakarta: Bina Aksara, 1985), hal. 6.

${ }^{39}$ Eddy Ruchiyat, Op. Cit., hal. 32.
} 
Sebelum muncul istilah beschikkingsrecht (hak ulayat), dahulu masih menggunakan istilah "hak milik asli" (eigendomsrecht) dan "hak milik komunal" (communaal bezitsrecht). ${ }^{40}$ Istilah-istilah ini ternyata menurut Barent Ter Haar ${ }^{41}$ dapat menyebabkan jalinan-jalinan yang ruwet terhadap terhadap hak masyarakat adat atas tanah, yang kemudian dapat berimplikasi pula terhadap kepastian hukum pada saat itu. Oleh sebab itu, atas jasa Cornelis van Vollenhoven diberi nama beschikkingsrecht untuk padanan istilah "hak ulayat" atau "hak pertuanan". Tegasnya, Cornelis van Vollenhoven ${ }^{42}$ menggarisbawahi bahwa, "Beschikkingsrecht adalah suatu hak atas tanah yang ada hanya di Indonesia, suatu hak yang tidak dapat dipecah-pecahkan dan mempunyai dasar keagamaan (religie). Hak tersebut tidak ada sangkut pautnya dengan hukum perdata eropa (BW).

Dalam buku Een Adat - Wetboekje Voor Het Indonesie (1925), C.van Vollenhoven ${ }^{43}$ menegaskan sebagai berikut:

a. Beschikkingsrecht atas tanah hanya dapat dimiliki oleh per-sekutuan hukum (gemeenschappen) dan tidak dapat dimiliki oleh perseorangan;

b. Beschikkingsrecht tidak dapat dilepaskan untuk selama-lama-nya;

c. Jika hak itu dilepaskan untuk sementara, bilamana alasan selain kerugian untuk penghasilan-penghasilan yang hilang harus dibayar juga cukai (heffingen) oleh orang-orang asing, menurut hukum adat diwajibkan membayar kepada persekutuan hukum (gemeenschappen) yang memiliki tanah itu.

Jadi, hak ulayat (beschikingsrecht) atas tanah itu merupakan milik persekutuan hukum (gemeenschappen) masyarakat adat yang tidak dapat dilepaskan selama-lamanya serta tidak boleh dimiliki oleh perseorangan.

Hak ulayat per-definisi menurut Surat Menteri Agraria/Kepala BPN Nomor 400-2626 tanggal 24 Juni 1999 Perihal Penyampaian dan Penjelasan Peraturan Menteri Negara Agraria/Kepala BPN Nomor 5 Tahun 1999 tentang Pedoman Penyelesaian Masalah Hak Ulayat Masyarakat Hukum Adat, dirumuskan sebagai berikut:

Kewenangan yang menurut hukum adat dipunyai oleh masyarakat hukum adat tertentu atas wilayah tertentu yang merupakan

${ }^{40}$ Ibid. Hak milik komunal (communaal bezitsrecht) ini menurut Djuhaendah Hasan dapat dicontohkan seperti: "Tanah Darti" di Ambon (Maluku), "Tanah Kalakerang" di Minahasa (Sulawesi Utara), adalah tanah komunal yang oleh masyarakat boleh menggunakannya secara bersama-sama tau bergiliran. Djuhaenda Hasan, Materi Kuliah Hukum Agraria Lanjut, pada tanggal 11 November 2002, Program Pascasarjana Universitas Padjadjaran, Bandung, 2002.

${ }^{41}$ B. Ter Haar, "Asas-Asas dan Susunan Hukum Adat”, (Jakarta: Pradnya Paramita, 1980), hal. $71-72$.

${ }^{42}$ Ibid., hal. 33.

${ }^{43} \mathrm{Ibid}$. 
lingkungan hidup para warganya untuk mengambil manfaat dari sumber daya alam, termasuk tanah. dalam wilayah tersebut, bagi kelangsungan hidup dan kehidupannya, yang timbul dari hubungan secara lahiriyah dan batiniah turun temurun dan tidak terputus antara masyarakat hukum adat tersebut dengan wilayah yang bersangkutan.

Untuk mengetahui apakah hak ulayat (beschikkingsrecht) itu masih ada, terdapat kriteria yang dapat digunakan sebagai parameter. Adapun kriteria untuk menentukan masih ada atau tidaknya hak ulayat menurut Maria S.W. Sumardjono, ${ }^{44}$ harus dilihat pada 3 (tiga) hal, yakni:

(1). Adanya masyarakat hukum adat yang memenuhi ciri-ciri tertentu, sebagi subyek hak ulayat;

(2). Adanya tanah/wilayah dengan batas-batas tertentu sebagai labensraum yang merupakan obyek hak ulayat; dan

(3). Adanya kewenangan masyarakat hukum adat untuk melakukan tindakan-tindakan tertentu sebagaimana diuraikan di atas."

Dipenuhinya ketiga persyaratan tersebut secara kumulatif, kiranya cukup obyektif sebagai kriteria penentu masih ada atau tidaknya hak ulayat, sehingga misalnya, walaupun ada masyarakat hukum dan ada tanah atau wilayahnya, namun apabila masyarakat hukum tersebut sudah tidak mempunyai kewenangan untuk melakukan tiga tindakan tersebut, maka hak ulayat dapat dikatakan sudah tidak ada lagi ${ }^{45}$ Justru itu, tanah-tanah ulayat seperti "tanah bengkok"46 dan "tanah titisara" "47 ataupun "tanah hak kaula" (di Aceh) yang lembaga desanya telah dihapuskan dan menjadi kelurahan, menjadi milik atau diserahkan kepemilikannya kepada pemerintah kabupaten atau kota. Sebab masyarakat hukum adat sudah tidak mempunyai kewenangan atas tanah-tanah ulayat tersebut. ${ }^{48}$

Perihal hak ulayat (beschikkingsrecht) secara yuridis (ius constitutum) telah diatur dalam Pasal 3 Undang-Undang Nomor 5 Tahun 1960 yang menegaskan bahwa:

Dengan mengingat ketentuan-ketentuan dalam Pasal 1 dan 2 pelaksanaan hak ulayat dan hak-hak yang serupa itu dari masyarakat-masyarakat hukum adat, sepanjang menurut ke-

${ }^{44}$ Maria S.W.Sumardjono, Op. Cit., hal 57.

${ }^{45}$ Ibid., hal. 57.

${ }^{46}$ yaitu tanah yang merupakan hak imbalan jabatan yang diberikan kepada kepala desa. Djuhaenda Hasan, Op. Cit.

${ }^{47}$ Ibid., yaitu tanah yang merupakan sumber kas pemeliharaan desa dan gaji pegawai desa.

${ }^{48}$ Ibid. 
nyataannya masih ada, harus sedemikian rupa sehingga sesuai dengan kepentingan nasional dan negara, yang berdasarkan atas persatuan bangsa serta tidak boleh bertentangan dengan undangundang dan peraturan-peraturan lain yang lebih tinggi.

Norma yang terkandung dalam Pasal 3 Undang-Undang Nomor 5 Tahun 1960 tersebut, kemudian lebih dijelaskan bahwa: ${ }^{49}$

Ketentuan ini pertama-tama berpangkal pada pengakuan adanya hak ulayat itu di dalam hukum agraria yang baru. Sebagaimana diketahui biarpun menurut kenyataannya hak ulayat itu ada dan berlaku serta diperhatikan pula di dalam keputusan-keputusan hakim, belum pernah hak tersebut diakui secara resmi di dalam undang-undang, dengan akibat bahwa di dalam melaksanakan peraturan-peraturan agraria hak ulayat itu pada zaman penjajahan dulu sering kali diabaikan. Berhubung dengan disebutnya hak ulayat di dalam UUPA yang pada hakekatnya berarti pula pengakuan hak itu, maka pada dasarnya hak ulayat itu akan diperhatikan, sepanjang hak tersebut menurut kenyataannya memang masih ada pada masyarakat hukum yang bersangkutan.

Memaknai dan memahami maksud para perumus UUPA, khususnya yang menyangkut Pasal 3 tersebut di atas, maka sudah semestinya hak ulayat masyarakat hukum adat dijadikan sebagai salah satu prinsip dasar dalam kebijakan pertanahan di Indonesia. Hal ini relevan dengan pendapat Maria S.W. Sumardjono yang menegaskan bahwa prinsip-prinsip dasar UUPA adalah (1). Prinsip Negara Menguasai; (2). Prinsip penghormatan terhadap hak atas tanah masyarakat hukum adat, (3). Asas fungsi sosial semua hak atas tanah, (4). Prinsip landreform, (5). Prinsip perencanaan dalam penggunaan tanah dan upaya pelestariannya, dan (6). prinsip nasionalitas. ${ }^{50}$

\section{Karakter Produk Hukum Berkenaan Keagrariaan Nasional Di Era Reformasi}

Meskipun dilihat dari sisi periodisasi rezim terdapat perbedaan, yakni, periode demokrasi terpimpin $(1959$ - 1966), periode orde baru $(1966$ - 1998) dan periode era reformasi (1998 - sekarang), namun undang-undang pokok yang mengatur keagrariaan nasional hanya satu yaitu Undang-Undang Nomor 5 Tahun 1960. Hanya saja, apabila dilihat dari segi undang-undang non-organiknya (undang-undang pendukung-nya) terdapat perbedaan-perbedaan yang mencolok.

${ }^{49}$ Darwin Ginting, "Kepastian Hukum Hak Atas Tanah Bagi Penanaman Modal Bidang Agrrobisnis di Indonesia", (Bandung: Unpad Press, 2009), hal. 93.

${ }^{50}$ Maria S.W.Sumardjono, Op. Cit., hal. 42. 
Demikian pula apabila dilihat dari segi pelaksanaan Undang-Undang Nomor 5 Tahun 1960, maka ada kecenderungan bahwa lebih ortodoks/konservatif/elitis pada masa orde baru ketimbang pada masa demokrasi terpimpin dan pada era refromasi. Moh.Mahfud $\mathbf{M D}^{51}$ menyimpulkan bahwa karakter produk hukum agraria sangat responsif pada periode demokrasi terpimpin yang nota bene otoriter, yakni sebagai berikut:

Pengecualian atas kesimpulan umum ini hanya terjadi dalam hukum agraria yang pada periode demokrasi terpimpin (yang otoriter) berkarakter sangat responsif. Tetapi hal ini dapat dijelaskan empat hal, yakni: Pertama, UUPA disahkan berdasarkan rancangan yang telah disiapkan oleh periode sebelumnya. Kedua, UUPA membongkar dasar-dasar kolonialisme yang ditentang oleh seтиa pemerintah Indonesia tanpa tergantung pada konfigurasi politiknya. Ketiga, UUPA memuat materi yang tidak menyangkut hubungan kekuasaan. Keempat, UUPA tidak semata-mata memuat bidang hukum administrasi negara, tetapi juga memuat bidang hukum keperdataan.

Alasan-alasan yang coba disodorkan Mahfud tersebut memberikan pemahaman bahwa sesungguhnya cetak biru (blue print) UUPA ada sejak masa periode kekuasaan pemerintahan demokrasi liberal (1945 - 1959), yang memang pada saat itu masih melihat hukum sebagai "panglima", bukan politik sebagai "panglima" (masih tegaknya supremasi hukum). Oleh karenanya, karakter produk hukum agrarianya cenderung responsif. Sebagaimana pendapat Mahfud ${ }^{52}$ lainnya yang menyatakan bahwa:

Pada periode ini (periode demokrasi liberal, penulis) pemerintah bersungguh-sungguh untuk membuat hukum agraria yang responsif atau sesuai dengan rasa keadilan dalam masyarakat. Meskipun belum ada hukum agraria nasional yang komprehensif, tetapi dari produkproduknya yang parsial itu, dapat dilihat dengan jelas hukum agraria pada periode ini berkarakter sangat responsif.

Andaikan cetak biru UUPA tersebut di atas dibentuk pada saat periode demokrasi liberal, besar kemungkinan materi muatan (het onderwerp) UUPA itu akan berwatak konservatif/ortodoks/elitis. Sedangkan alasan Mahfud yang lain adalah bahwa UUPA itu tidak langsung bersentuhan dengan kekuasaan (politik) pemerintah pada saat itu. Sebagaimana diketahui bahwa UUPA tidak semata-mata hanya bermuatan hukum administrasi negara, akan tetapi juga bermuatan hukum keperdataan.

Karakter responsif UUPA pada periode demokrasi terpimpin di atas, kemudian mendapat interpretasi yang mengarah ke sifat konservatif oleh

\footnotetext{
${ }^{51}$ Moh. Mahfud. MD, Op. Cit., hal. 355.

${ }^{52}$ Ibid., hal. 344.
} 
pemerintah orde baru yang menyebabkan sehingga disimpulkan bahwa karakter produk hukum agraria nasional pada periode orde baru terlihat ortodoks/konservatif/elitis. Untuk lebih jelasnya dapat disimak pendapat Moh. Mahfud MD, ${ }^{53}$ sebagai berikut:

Terhadap UUPA yang sebenarnya responsif itu telah dilakukan interpretasi pemerintah melalui bentuk-bentuk peraturan per-undangundangan yang cenderung konservatif. Memang sebagai produk hukum yang tidak menyangkut gezagverhouding dan mencakup hukum publik dan privat, UUPA berkarakter responsif, tetapi interpretasi pemerintah dalam bentuk peraturan perundang-undangan secara parsial untuk keperluan pragmatis dalam rangka pelaksanaan program-program pembangunan memperlihatkan wa-tak yang konservatif. Adanya Keppres Nomor 55 Tahun 1993 (Pengadaan Tanah Bagi Pelaksanaan Pembangunan Untuk Ke-pentingan Umum), meskipun membawa sedikit kemajuan, namun bentuk peraturannya tetap tidak proporsional. Materinya yang prinsip seharusnya menjadi materi undang-undang yang tidak dibuat sepihak oleh eksekutif.

Terlihat benar bahwa letak konservatifnya produk hukum agraria nasional di masa orde baru bukan terletak pada UUPAnya, melainkan pada peraturan perundang-undangan lain yang menyangkut keagrariaan. Contoh yang dikemukakan Mahfud adalah Keputusan Presiden Nomor 55 Tahun 1993 Tentang Pengadaan Tanah Bagi Pelaksanaan Pembangunan Untuk Kepentingan Umum. Tetapi dengan lahirnya Undang-Undang nomor 2 Tahun 2012 tentang Pengadaan Tanah Bagi Pembangunan Untuk Kepentingan Umum, menunjukkan terdapat semangat yang responsive.

Watak konservatif/ortodoks/elitis produk hukum agraria nasional pada masa orde baru tersebut di atas, kemudian menjadi responsif kembali pada masa reformasi. Hal ini ditandai dengan keluarnya Peraturan Menteri Agraria/Kepala Badan Pertanahan Nasional Nomor 5 Tahun 1999 tentang Pedoman Penyelesaian Masalah Hak Ulayat Masyarakat Hukum Adat. Adapun dasar pertimbangan keluarnya Peraturan Menteri Agraria/Kepala BPN ini adalah sebagai berikut:

Bahwa dalam kenyataannya pada waktu ini banyak daerah masih terdapat tanah-tanah dalam lingkungan masyarakat hukum adat yang pengurusan, penguasaan dan penggunaannya didasarkan pada ketentuan hukum adat setempat dan diakui oleh para warga masyarakat hukum adat yang bersangkutan sebagai tanah ulayatnya.

Berangkat dari dasar pertimbangan filosofis dan sosiologis ini merupakan sinyalemen karakter hukum agraria yang mulai cenderung responsif. Artinya, perhatian pemerintah di era reformasi yang nota bene berkonfigurasi politik

${ }^{53}$ Ibid., hal. $354-355$. 
demokratis, kembali memperhatikan masyarakat secara egalistis (merakyat), yakni kembali melindungi hak-hak rakyat dalam bidang pertanahan, khususnya yang menyangkut hak-hak adat atas tanah, terutama hak ulayat. Agar tercipta keteraturan mekanisme dalam pengadaan tanah bagi pembangunan, maka kemudian dikuatkan dengan Peraturan Presiden Nomor 36 Tahun 2005 jo Peraturan Presiden No.65 Tahun 2006 tentang Pengadaan Tanah Untuk Pembangunan. Meskipun demikian, Perpres ini menurut hemat penulis perlu dinaikkan status bentuk hukumnya menjadi materi muatan undang-undang, karena pelepasan hak seorang atas tanah sangat tersangkut paut dengan hak-hak asasi manusia (human rights). Hal tersebut telah direspon oleh pemerintah dengan disahkannya undang-undang No. 2 Tahun 2012 tentang Pengadaan Tanah Bagi Pembangunan Untuk Kepentingan Umum.

Tabel 1. Hubungan konfigurasi politik terhadap kecenderungan karakter produk hukum agraria sejak 1945 sampai sekarang adalah:

\begin{tabular}{||c|c|c|c||}
\hline \hline No & Periode & $\begin{array}{c}\text { Konfigurasi } \\
\text { Politik }\end{array}$ & $\begin{array}{c}\text { Kecenderungan Kararkter } \\
\text { Produk HukumAgraria }\end{array}$ \\
\hline \hline 1 & $\begin{array}{c}\text { 1945-1959 } \\
\text { (Demokrasi Liberal) }\end{array}$ & Demokratis & Responsif \\
\hline \hline 2 & $\begin{array}{c}1959-1966 \\
\text { (Demokrasi } \\
\text { Terpimpin) }\end{array}$ & Otoriter & Responsif \\
\hline \hline 3 & $\begin{array}{c}\text { 1966-1998 } \\
\text { (Orde Baru) }\end{array}$ & Otoriter & $\begin{array}{c}\text { Ortodoks/ Konservatif/ } \\
\text { Elitis }\end{array}$ \\
\hline \hline & $\begin{array}{c}\text { 1998-skarang } \\
\text { (reformasi) }\end{array}$ & $\begin{array}{c}\text { Demokrati } \\
\text { s }\end{array}$ & Responsif \\
\hline
\end{tabular}

Sumber: Mahfud MD. Moh, Politik Hukum di Indonesia, Pustaka LP3ES Indonesia, Jakarta, 1998.

\section{Arah Politik Hukum Agraria Nasional dan Keberadaan Hak Ulayat Masyarakat Hukum Adat Dalam Menghadapi Globalisasi}

Sebagaimana penulis telah ungkapkan sebelumnya bahwa kecenderungan produk hukum agraria nasional ke depan akan lebih responsif. Hal ini sejalan dengan kenyataan politik pemerintahan yang demokratis sekarang, sehingga berimplikasi terhadap watak produk hukum agraria, yakni berkarakter responsif. Dalam artian bahwa rechtbeleid (kebijakan hukum) pemerintah dalam bidang pertanahan mulai memperhatikan hak-hak adat masyarakat terhadap tanah. Pertanyaannya sekarang adalah bagaimanakah arah politik hukum agraria nasional bila dikaitkan dengan keberadaan hak ulayat masyarakat hukum adat dalam menghadapi era globaliosasi?. Untuk menjawab pertanyaan ini, maka terlebih dahulu penulis menjelaskan arah politik hukum agraria nasional di era reformasi.

Telah dijelaskan pada pembahasan sebelumnya bahwa arah politik hukum itu terdapat beberapa kemungkinan, seperti unifikasi hukum, pluralisme hukum, 
penyederhanaan hukum dan sebagainya. Untuk arah politik hukum agraria nasional adalah pluralisme hukum dan penyelarasan hukum. Maksud pluralisme hukum agraria nasional adalah bahwa pada era reformasi tidak akan dibentuk suatu penyatuan hukum agraria yang bersifat nasional, akan tetapi masih disandarkan pada hukum adat masing-masing, termasuk yang menyangkut hak ulayat masyarakat adat. Sebagaimana pula yang telah termaktub dalam konsiderans UUPA yang menegaskan bahwa: hukum agraria tersebut mempunyai sifat dualisme, dengan berlakunya hukum adat di samping hukum agraria yang didasarkan hukum barat. Jadi, istilah dualisme menurut UUPA, sama maknanya dengan pluralisme seperti pendapat penulis.

Maksud "penyelarasan hukum agraria nasional" adalah. Pertama, bahwa hukum agraria yang disandarkan pada hukum adat berdasarkan pluralisme hukum akan diselaraskan dengan kepentingan nasional ke depan. Kedua, bahwa hukum agraria yang didasarkan pada hukum adat akan diselaraskan dengan keadaan dunia yang semakin mengglobal, sehingga dibutuhkan modernisasi hukum agraria nasional yang tidak meninggalkan nilai-nilai budaya masyarakat yang berkenaan dengan tanah. Argumentasi ini terkait dengan pendapat Mochtar Kusumaatmadja $^{54}$, yang mengatakan bahwa:

...dalam proses pertumbuhan budaya nasional, pembinaan budaya bangsa yang berakar pada kebudayaan daerah yang beraneka ragam itu tidak bisa diisolasikan dari pengaruh luar... Karena di dalam pergaulan masa kini bangsa Indonesia tidak dapat lagi memencilkan dirinya atau mencegah pergaulan atau kompetisi dengan bangsa lain, maka mau tidak mau kita harus sedapat mungkin berusaha memiliki sifat-sifat yang berlaku umum (uni-versal)...Indonesia mempunyai keadaan yang tersendiri atau unik, dalam arti bahwa walaupun pada satu pihak manusia Indonesia tidak dapat mengisolasikan dirinya dari pergaulan dengan bangsa lain sebagai akibat dari perhubungan dan komunikasi antara bangsa yang sudah intensif sekarang, di pihak lain ia masih dekat sekali bahkan dalam beberapa hal masih terikat oleh adat ke-biasaan dan tradisi-tradisi tempat asalnya.

Hukum agraria nasional-pun demikian, tidak bisa diisolasikan (dikungkung) dari perkembangan global yang lebih modern. Meskipun harus diakui bahwa sebagian besar masyarakat Indonesia masih terikat dengan adat kebiasaannya terhadap tanah, seperti halnya hak ulayat (beschikkingsrecht) itu sendiri.

Sehubungan dengan pendapat Mochtar di atas, maka arah politik hukum agraria nasional ke depan dalam menghadapi globalisasi adalah tetap dalam kerangka pluralisme dan penyelarasan hukum, yakni dengan memparalelkan antara kepentingan masyarakat adat dalam bentuk hak ulayat yang masih ada dengan kepentingan pembangunan ekonomi nasional yang membutuhkan peranan

${ }^{54}$ Mochtar Kusumaatmadja, Tradisi dan Pembaharuan Di Negara Sedang Berkembang, Naskah Pidato Kuliah Perdana Program Pascasarjana Universitas Padjadjaran, Bandung, 21 Oktober 1996, 1 -27 
hukum agraria nasional yang lebih besar. Justru itu, agar hak ulayat masyarakat adat ini tidak "mengada-ada" atau "diada-adakan", maka perlu dibuat satu disain riset (research design) yang menentukan masih ada atau sudah tidak ada hak ulayat. Indikator yang dapat dijadikan penelitian dimaksud patokan adalah: ${ }^{55}$

a. Unsur masyarakat adat, yaitu terdapatnya sekelompok orang yang masih merasa terikat oleh tatanan hukum adatnya sebagai warga bersama suatu persekutuan hukum tertentu, yang mengakui dan menerapkan ketentuan-ketentuan persekutuan tersebut dalam kehidupannya sehari-hari.

b. unsur Iwilayah, yaitu terdapatnya tanah ulayat tertentu yang menjadi lingkungan hidup (labensraum) para warga persekutuan hukum tersebut dan tempatnya mengambil keperluan hidupnya sehari-hari, dan

c. unsur hubungan antara masyarakat tersebut dengan wilayahnya, yaitu terdapatnya tatanan hukum adat mengenai pengurusan, penguasaan dan penggunaan tanah ulayatnya yang masih berlaku dan ditaati oleh warga persekutuan huykum tersebut.

Penelitian mengenai ketiga unsur tersebut di atas dan penentuan masih adanya hak ulayat dapat dilakukan oleh Pemerintah Daerah (baik oleh pemerintah provinsi maupun kabupaten dan kota) dengan mengikut-sertakan pihak-pihak yang berkepentingan dan pihak-pihak yang dapat menyumbangkan peranannya secara obyektif, yaitu antara lain para tetua adat (tokoh adat), para pakar adat, wakil Lembaga Swadaya Masyarakat (LSM) dan wakil instansi yang bertanggung jawab mengenai pengelolaan sumber daya alam (misalnya: instansi kehutanan, pertambangan dan sebagainya, apabila tanah ulayat itu diperkirakan meliputi tanah yang ada hutan atau bahan tambangnya) ${ }^{56}$ Apabila dalam hasil penelitian mengenai penentuan masih adanya hak ulayat menunjukkan bahwa sama sekali tidak ada hak ulayat, maka dengan sendirinya pemilikan, penggunaan dan pengelolaan tanah di wilayah penelitian tersebut harus tunduk pada sistem hukum agraria nasional.

Dalam rangka mewujudkan politik hukum agraria yang responsif dan sesuai dengan tuntutan era reformasi, maka perlu dilakukan langkah-langkah yang strategis sehingga dapat mengeliminir setidak-tidaknya memperkecil kemungkinan terjadinya konflik dan sengketa tanah hak ulayat, maka perlu dilakukan pemetaan terhadap hak ulayat di Indonesia. Sebagaimana Negara tetangga kita Malaysia telah melakukan pemetaan hak ulayat atau di Negara Malaysia disebut tanah simpanan melayu semenjak tahun delapanpuluhan. ${ }^{57}$ Menurut penulis, pendataan luas hak ulayat dalam bentuk pemetaan seyogyanya 1999.

${ }^{55}$ Lihat: Surat Menteri Negara Agraria/Kepala BPN Nomor 400 - 2626, tanggal 24 Juni

${ }^{56} \mathrm{Ibid}$.

${ }^{57}$ Moh. Ridwan Bin Awang, "Tanah Simpanan Melayu”, (Malaysia: Rich'me Enterprise, 1987), hal. 4. 
harus dilakukan secara cermat dan hati-hati, sehingga dapat mencegah atau setidak-tidaknya memperkecil kemungkinan terjadinya konflik dan sengketa tanah hak ulayat seperti kasus belakangan ini tentang lahan kebun kelapa sawit di pulau Sumatera ,Sulawesi dan Kalimantan atau kasus Freeport di Papua sampai hari ini belum tuntas. ${ }^{58}$ Upaya pendataan luas hak ulayat bukan berarti mempertahankan keberadaannya, karena hak ulayat akan terhapus secara alamiah karena dampak pembangunan yang berjalan terus. Hal ini terbukti di pulau jawa tidak ada lagi hak ulayat karena pembangunan fisik dan nonfisik hampir telah merata. Dampak positif lanjutan dari upaya pendataan hak ulayat kedepan dapat menunjang kepastian hukum bagi masyarakat adat secara khusus dan Hukum Tanah Nasional pada umumnya.

\section{Simpulan}

1) bahwa arah kebijakan hukum (legal policy) agraria berkenaan dengan hukum adat dan hak ulayat (beschikkingsrecht) masyarakat adat pada masa penjajahan Belanda sesungguhnya berkeinginan untuk unifikasi dan kodifikasi hukum pertanahan yang berlaku untuk seluruh golongan masyarakat (termasuk golongan pribumi) berdasarkan asas konkordansi. Namun pelaksanaan legal policy ini gagal total, sehingga tetap diterapkan kebijakan pluralisme hukum.

2) bahwa arah kebijakan hukum (legal policy) agraria nasional pada era reformasi berkenaan dengan hak ulayat masyarakat hukum adat tetap pada kebijakan pluralisme hukum sebagaimana yang diamanatkan dalam konstitusi khususnya Pasal 18B ayat (2) UUD 1945 yang menegaskan: "Negara mengakui dan menghormati kesatuan-kesatuan masyarakat hukum adat beserta hak-hak tradisionalnya sepanjang masih hidup dan sesuai dengan perkembangan masyarakat dan prinsip Negara Kesatuan Republik Indonesia yang diatur dalam undang-undang. "Kemudian dalam Pasal 28I ayat (3) UUD 1945 ditegaskan bahwa: "Identitas budaya dan hak masyarakat tradisional dihormati selaras dengan perkembangan jaman dan peradaban". Kemudian ditindaklanjuti dengan keluarnya Peraturan Menteri Negara Agraria/Kepala Badan Pertanahan Nasional Nomor 5 Tahun 1999 tentang Pedoman Penyelesaian Masalah Hak Ulayat Masyarakat Hukum Adat. Materi muatan Permen ini sangat relevan dengan perlindungan hak-hak masyarakat adat dalam UUD 1945.

3) bahwa prospek hak ulayat masyarakat hukum adat dalam menghadapi terpaan globalisasi masih perlu dipertahankan melalui cara mengkombainnya dengan upaya pembaharuan hukum lewat penelitian (riset) tentang ada tidaknya hak ulayat masyarakat hukum adat di setiap daerah. Dari hasil penelitian perlu di tindak lanjuti dengan melakukan pemetaan hak ulayat sesuai dengan kaidah-kaidah Ilmu Geodesi, sehingga

${ }^{58}$ Darwin Ginting, "Hukum Kepemilikan Hak Atas Tanah Bidang Agribisnis", (Jakarta: Gahlia Indonesia, 2010), hal. 195. 
terlihat jelas luasan hak ulayat yang ada di Nusantara dan pada akhirnya dapat berkontribusi dalam menunjang eksistensi dan kepastian hukum hak ulayat secara khusus dan Hukum Tanah Nasional pada umumnya. 


\section{Daftar Pustaka}

Afandi, Ali. Kedudukan Hukum Asing Dalam Pembinaan Tata Hukum Di Indonesia, Jakarta: Bina Aksara, J1985.

Anaya, S. James. Indegenous Peoples International Law, New York: Oxford University Press, 1994.

Buang, Saleh. Undang-Undang Tanah di Malaysia, Selangor Darul Eksam: Dewan Bahasa dan Pustaka Lot 1037, 1993.

Ginting, Darwin. Kepastian Hukum Hak Atas Tanah Bagi Penanaman Modal Bidang Agribisnis di Indonesia, Bandung: Unpad Press, Tahun 2009.

Hukum Kepemilikan Hak Atas Tanah Bidang Agribisnis, Jakarta: Gahlia Indonesia, Tahun 2010.

Haar, Ter, B. Asas-Asas dan Susunan Hukum Adat, Jakarta: Pradnya Paramita, 1980.

Harsono, Boedi. Hukum Agraria Indonesia; Himpunan Peraturan-Peraturan Hukum Tanah, Jakarta: Djambatan, 2002.

. Hukum Agraria Indonesia; Sejarah Pembentukan UndangUndang Pokok Agraria, Isi dan Perkembangannya, Jakarta: Djambatan, 2003.

Hartono, Sunaryati, C.F.G. Politik Hukum Menuju Satu Sistem Hukum Nasional, Bandung: Alumni, 1991.

Hasan, Djuhaenda. Materi Kuliah Hukum Agraria Lanjut, pada tanggal 11 November 2002, Program Pascasarjana Universitas Padjadjaran, Bandung, 2002.

Hutagalung, S. Arie. Tebaran Pemikiran Seputar Masalah Hukum Tanah, Jakarta: Lembaga Pemberdayaan Hukum Indonesia (LPHI), 2005.

Kusumaatmadja, Mochtar. Tradisi dan Pembaharuan Di Negara Sedang Berkembang, Naskah Pidato Kuliah Perdana Program Pascasarjana Universitas Padjadjaran, Bandung, 21 Oktober 1996.

Kansil, C.S.T. Pengantar Ilmu Hukum dan Tata Hukum Indonesia, Jakarta: Balai Pustaka, 1989.

Mahfud MD, Moh. Politik Hukum Di Indonesia, Jakarta: Pustaka LP3ES Indonesia, 1998.

Martosoewignjo, Sri Soemantri. Materi Kuliah Politik Hukum, Bandung: Program Pascasarjana Universitas Padjadjaran, 2002.

Parlindungan, AP. Konversi Hak-Hak Atas Tanah, Bandung: Mandar Maju, 1994. 
Purbacaraka, Purnadi \& Soerjono Soekanto. Disiplin Hukum dan Disiplin Sosial, Jakarta: Rajawali, 1986.

Ridwan, Moc. Bin Awang. Tanah Simpanan Melayu, Malaysia: Rich'me Enterprise, 1987.

Rudy, Teuku May. Masalah Negara Berkembang; Suatu Kajian Ekonomi Politik Internasional, Bandung: Bina Budaya, 2004.

Ruchiyat, Eddy. Politik Pertanahan Nasional Sampai Orde Reformasi, Bandung: Alumni, 1999.

Sumardjono, Maria S.W. Kebijakan Pertanahan; Antara Regulasi dan Implementasi, Jakarta: Penerbit Buku Kompas, 2001.

Syarif, Amiroeddin. Perundang-Undangan; Dasar, Jenis dan Teknik Membuatnya, Jakarta: Bina Aksara, 1987.

Tim Penyusun Kamus Pusat Pembinaan dan Pengembangan Bahasa. Kamus Besar Bahasa Indonesia, Jakarta: Departemen Pendidikan dan Kebudayaan bekerja sama dengan Balai Pustaka, 1995.

Wargakusumah, Hasan, et.al. Hukum Agraria; Buku Panduan Mahasiswa, Jakarta: Prenhallindo, 2001.

Wahyono, Padmo. Menyelidik Proses Terbentuknya Perundang-undangan, Jakarta: Forum Keadilan, 1992.

Wignjosoebroto, Soetandyo, Dari Hukum Kolonial Ke Hukum Nasional; Suatu Kajian Tentang Dinamika Sosial - Politik Dalam Perkembangan Hukum Selama Satu Setengah Abad di Indonesia (1840 - 1990), Jakarta: RajaGrafindo Persada, 1995.

\section{Jurnal/Koran}

"Berdayakan Masyarakat Hukum Adat untuk Perlindungn Lingkungan", Tempt/HOCVPO7L: 1.

Chaidir, Ellydar, "Desentralisasi Pengelolaan Sumber Daya Alam Dalam Perpektif Undang-Undang Nomor 22 Tahun 1999", Jurnal Hukum Ius Quia Iustum No. 14 Vol. 7 Universitas Islam Indonesia, Yogyakarta, 2000.

Harian Kompas, tanggal 29 Mei 2012.

Pryo, Sarjono Agung, "Konflik Sosial di Kalimantan Timur", Hutan Indonesia, Edisi 07, II/Maret 2000: 14

\section{Peraturan Perundang-undangan}

Undang-Undang Dasar 1945. 
Undang-Undang Nomor 5 Tahun 1960 tentang Peraturan Dasar PokokPokok Agraria.

Undang-Undang Nomor 32 Tahun 2004 tentang Pemerintahan Daerah.

Undang-Undang Nomor 7 Tahun 2004 tentang Sumber Daya Air.

Undang-undang Nomor 14 Tahun 2004 tentang Perkebunan.

Undang-undang Nomor 1 Tahun 2003 tentang Ketentuan-ketentuan Pokok Kehutanan.

Undang-undang Nomor 4 Tahun 2009 tentang Pertambangan.

Surat Menteri Negara Agraria/Kepala BPN Nomor 400 - 2626, tanggal 24 Juni 1999. 